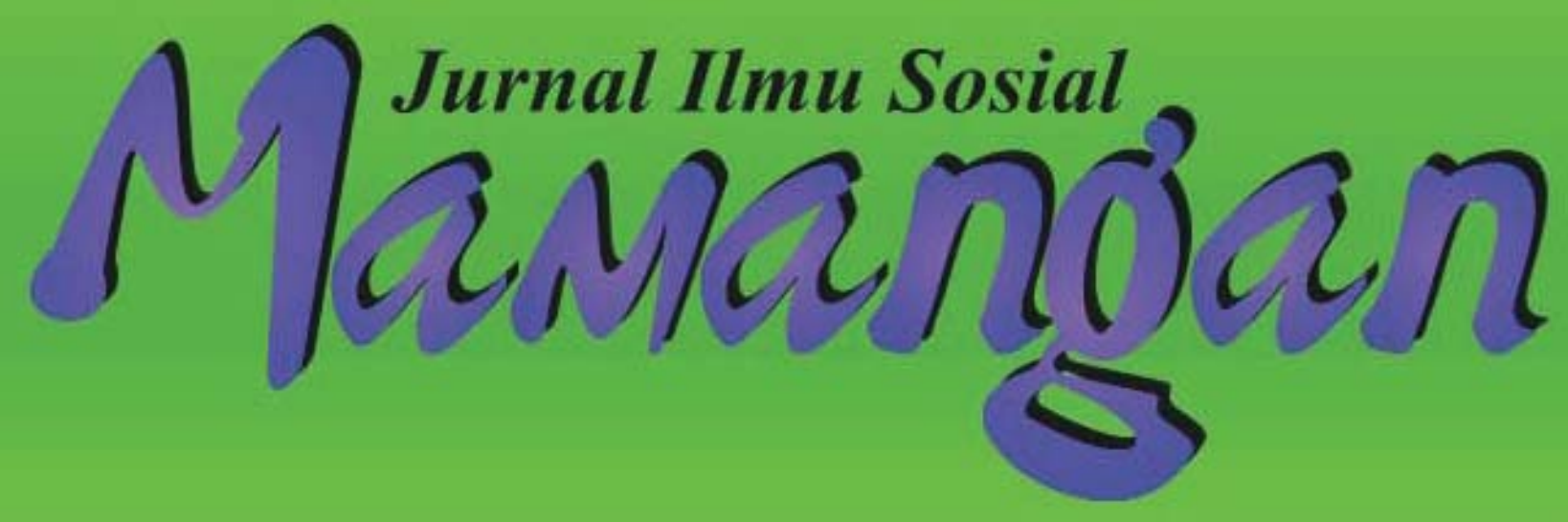

Beberapa Hipotesis Tentang Eksklusi Sosial di Indonesia Robert M.Z. Lawang

Dapatkah Indonesia Bebas Dari Kutukan Kolonial?

Refleksi Kritis Atas MP3EI

Noer Fauzi Rachman \& Dian Yanuardy

Rontoknya Dominasi Negara di Tambang Batu Bara Ombilin Sawahlunto

Zaiyardam Zubir \& Zulqayyim

Protes Korban Bencana; Studi Konflik Penanggulangan Bencana di Pasar Raya Padang

Firdaus

Peran Perempuan dalam Resolusi Konflik Rehabilitasi dan Rekonstruksi Pasar Raya Padang Ira Ariesta

Resolusi Konflik Berbasis Adat; Studi Resolusi Konflik Harta Pusaka Tinggi di Nagari Gantuang Ciri, Kab. Solok, Sumatera Barat

Yuhelna

Nelayan Vs Rentenir; Studi Ketergantungan Nelayan terhadap Rentenir pada Masyarakat Pesisir Delmira Syafrini 


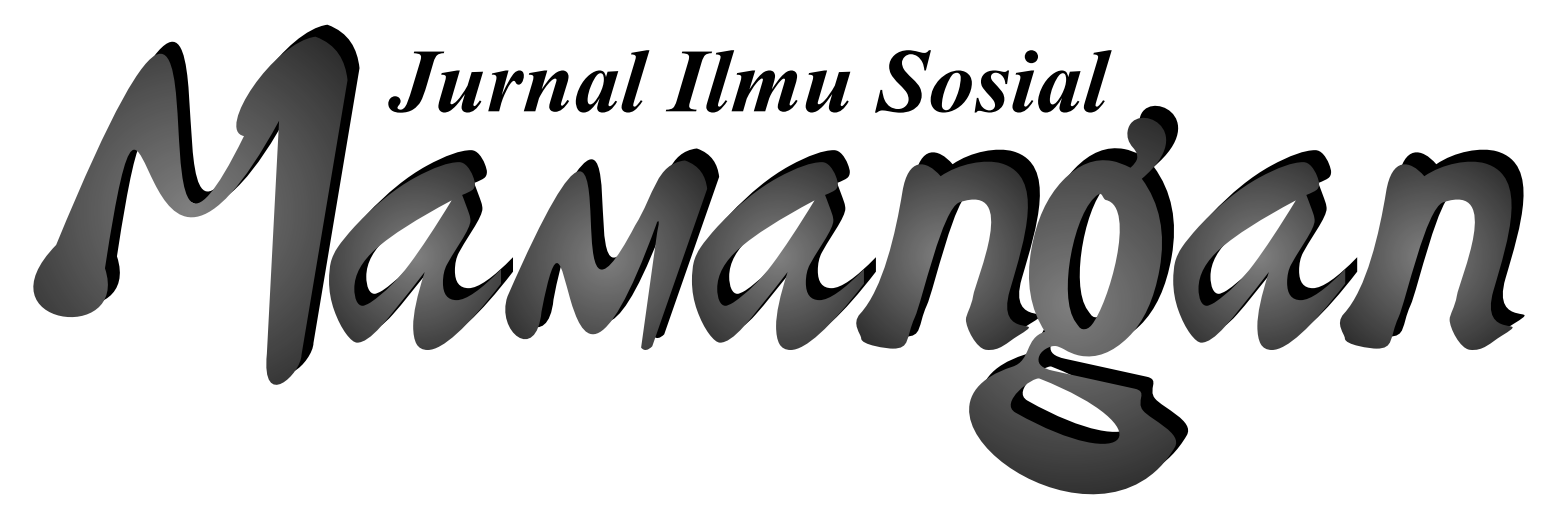




\section{Mitra Bestari}

Prof. Dr. Afrizal, MA. (FISIP, Unand Padang)

Prof. Dr. Badaruddin, M. Si. (FISIP, USU Medan)

Dr. A. Latief Wiyata, M. Si. (Universitas Jember, Jember)

Dr. Fikarwin Zuska, M. Si. (FISIP, USU Medan)

Nurus Shalihin, M. Si., Ph.D. (Fak. Ushuluddin IAIN Imam Bonjol Padang)

Dr. Semiarto A. Purwanto, M. Si. (FISIP, UI Jakarta)

Dr. Wahyu Wibowo, M. Si. (Universitas Nasional, Jakarta)

\section{Dewan Redaksi}

Dr. Zusmelia, M. Si.

Dr. Maihasni, M. Si.

Firdaus, S. Sos., M. Si.

\section{Pemimpin Redaksi/Editor}

Firdaus, S. Sos., M. Si.

\section{Anggota Redaksi}

Dian Kurnia Anggreta, S. Sos., M. Si.

Rinel Fitlayeni, S. Sos., MA.

Rio Tutri, M. Si

Sri Rahayu, M. Pd

Surya Prahara, SH,. MH.

Yuhelna, MA.

ISSN: 2301-8496

viii +81 halaman, $21 \times 29 \mathrm{~cm}$

\section{Alamat Redaksi:}

Laboratorium Program Studi Pendidikan Sosiologi, STKIP PGRI Sumbar Kampus STKIP PGRI, Jl. Gunung Pangilun, Padang, Sumatera Barat

Email: redaksimamangan@yahoo.com \& daus_gila@yahoo.com

\section{Penerbit:}

Laboratorium Program Studi Pendidikan Sosiologi, STKIP PGRI Sumbar

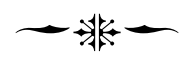




\section{PENGANTAR REDAKSI}

K onflik dalam masyarakat merupakan keniscayaan. Ia akan terus menjadi bagian dalam dinamika kemasyarakatan dan mengejawantah dalam berbagai bentuk yang secara garis bersar dikategorikan sebagai bentuk laten dan bentuk manifest. Pola dan bentuk konflik juga terus mengalami perkembangan sesuai dengan tingkat perkembangan masyarakat dimana konflik tersebut ada. Pola dan bentuk itu, mulai dari yang sederhana hingga yang paling 'canggih' dan bahkan disengaja ada untuk kepentingan tertentu oleh kelompok tertentu.

Meskipun para penganut fungsionalisme meganggap bahwa konflik dalam kehidupan sosial adalah abnormal (Johnson, 1994:161), namun konflik di lain kesempatan merupakan fakta sosial yang bisa fungsional bagi struktur tertentu selama ia dikelola dengan baik. Maka konflik kemudian di beberapa kesempatan juga dibutuhkan untuk kepentingan-kepentingan tertentu. Sehingga dengan demikian, adakalanya konflik mengikuti polanya sendiri dan adakalanya seirama dengan perkembangan masyarakat.

Menyadari bahwa perkembangan masyarakat terus melaju ke bentuk yang lebih kompleks, dan asumsi bahwa konflik juga akan kompleks sesuai dengan perkembangan kompleksitas masyarakat, Mamangan Edisi II yang ada di tangan pembaca ini mengambil konflik sebagai tema umum. Dalam edisi ini konflik dilihat oleh penulis dalam berbagai dimensi melalui berbagai pendekatan, baik secara teoritis maupun empiris melalui studi lapangan. Beberapa pakar di bisangnya telah menyumbang dalam dalam edisi kedua ini.

Tulisan pertama disumbangkan oleh Prof. Robert Lawang yang mendiskusikan konsep eksklusi sosial dalam konteks sosial, ekonomi dan politik. Tiga ranah ini menurut Lawang dikuasai arus utama (main stream) yang tidak mudah dimasuki oleh kelompok sosial tertentu dalam masyarakat paling bawah (underclass), sehingga mereka mengalami deprivasi. Selain itu, Lawang juga menyebut adanya perbedaan pandangan dan cara menjelaskan gejala sosial yang terkait eksklusi sosial. Meskipun konsep eksklusi sosial adalah konsep Barat, namun di Indonesia menurut Lawang, eksklusi sosial terjadi dalam berbagai struktur sosial masyarakat, baik di perkotaan maupun di pedesaan. 
Tulisan kedua disumbangkan oleh Noer Fauzi Rachman dan Dian Yanuardy yang mengupas secara kritis MP3EI. Dalam tulisannya, Fauzi dan Dian mempreteli skema MP3EI dan menyebutnya sebagai bagian dari upaya untuk memperdalam integrasi tanah air Indonesia ke dalam zona perdagangan bebas ASEAN dan Asia Timur. menurut mereka MP3EI pada pokoknya bertumpu pada upaya untuk melakukan reorganisasi ruang dalam rangka memperlancar interaksi dan aliran kapital, barang dan tenaga kerja untuk aktivitas produksi-konsumsi. Skema MP3EI dalam pola pemberian lisensi pada perusahaan untuk mengeksploitasi Sumber daya Alam menurutnya tidak jauh berbeda dengan kebijakan pemerintah kolonial Belanda sejak 1870, yang menempatkan Indonesia sebagai tempat produksi komoditas global.

Tulisan ketiga disumbangkan oleh Zayardam Zuber dan Zulqayim tentang rontoknya dominasi negara di Tambang Batubara Omblin, Sawahlunto. Zayardam dan Zulqayim dalam tulisannya mengemas sejarah beralihnya tambang di Kota Sawahlunto dari tangan perusahaan ke tangan rakyat yang selama puluhan tahun hanya menjadi penonton di arena tambang. Proses peralihan tersebut menurut Zayardan dan Zulqayim antara lain dilatari oleh penguasaan terhadap lahan di sekitar tambang yang dikuasi oleh dua kelompok, yaitu masyarakat adat dan pemerintah daerah. Selain itu, menurunnya aktivitas tambang PT. BA-UPO selaku BUMN yang kemudian menyerahkan pengurusan tambang kepada Pemda setempat juga menjadi bagian dari latar rontokya dominasi negara.

Tulisan keempat disumbangkan oleh Firdaus yang menguraikan protes korban bencana dalam proses rehabilitasi dan rekonstruksi di Pasar Raya Padang. Firdaus menyebutkan faktor penyebab munculnya protes adalah kebijakan pembangunan yang tidak partisipatif dan merugikan pedagang yang merupakan korban bencana. Kebijakan itu dibuat oleh pemerintah melalui mekanisme yang tidak sesuai dengan aturan yang ada. Protes yang dilakukan oleh korban bencana dilakukan dengan berbagai strategi, mulai dari strategi konfrontasi hingga negosiasi.

Tulisan kelima disumbangkan oleh Ira Ariesta yang mengulas peran perempuan dalam resolusi konflik Pasar Raya Padang. Ulasan Ira 'nyambung' dengan tulisan Firdaus sebelumnya. Jika Firdaus lebih menekankan pembahasan tentang penyebab dan strategi protes, maka Ira lebih menekankan pada resolusi konflik. Resolusi konflik yang dibahas Ira lebih fokus lagi pada peran perempuan. Menurut Ira, peran perempuan dalam proses resolusi konflik di Pasar Raya dilakukan oleh empat aktor utama, yaitu perempuan dari instansi pemerintah, perempuan aktivis LSM (PBHI Sumbar), perempuan aktivis mahasiswa dan perempuan pedagang. Keempat kelompok memainkan peran yang berbeda dalam resolusi konflik, mulai dari aksi massa hingga kegiatan advokasi terorganisir.

Tulisan keenam disumbangkan oleh Yuhelna yang membahas tentang mekanisme penyelesaian konflik harta pusaka tinggi secara adat di Minangkabau. Penyelesaian konflik harta pusaka tinggi di Minangkabau dilihat di nagari Gantuang Ciri. Resolusi konflik dilakukan pada 3 tingkatan. Tingkatan pertama resolusi konflik dilakukan di tingkat suku dengan melibatkan pangulu suku. Tingkat kedua resolusi konflik dilakukan pada tingkat yang lebih luas, yaitu pada institusi Tigo Niniak atau Ampek Niniak. Pada tingkat ini, resolusi konflik difasilitasi oleh niniak mamak masing-masing suku atau kaum yang berkonflik. Pada tingkat ketiga resolusi konflik dilakukan di lembaga adat Kerapatan Adat Nagari (KAN). Resolusi konflik pada tingkat ini difasilitasi oleh pengurus KAN yang merupakan perwakilan dari semua suku yang ada dalam nagari.

Tulisan terakhir, disumbangkan oleh Delmira Syafrini yang menganalisis ketergantungan nelayan dengan tengkulak di wilayah pesisir. Delmira melihat ketergantungan nelayan terhadap rentenir sebagai fenomena yang dilematis. Di satu sisi, nelayan mendapat kemudahan mengakses 
modal, di sisi lain nelayan dirugikan dengan suku bunga yang tinggi. Sementara, lembaga keuangan seperti Bank belum mampu menjadi katup penyelamat karena mekanisme rungguhan yang disyaratkan lembaga ini tidak terjangkau oleh nelayan. Di bagian akhir, Delmira menawarkan pemberdayaan sebagai solusi untuk memutus ketergantungan nelayan terhadap rentenir.

Demikianlah tulisan pada edisi ini, dan kepada para penyumbang tulisan pada edisi ini redaksi mengucapkan terima kasih atas karya intelektual dan buah pemikiran mereka, dan kepada para pembaca, redaksi mengucapkan selamat membaca. 



\section{DAFTAR ISI}

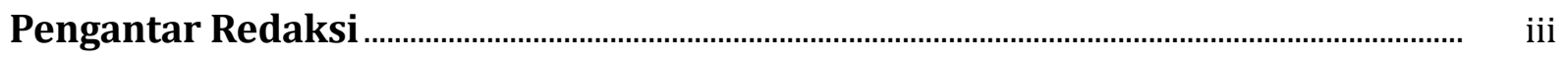

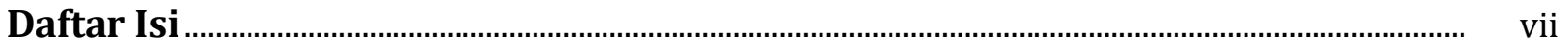

Beberapa Hipotesis Tentang Eksklusi Sosial di Indonesia

Robert M.Z. Lawang

Dapatkah Indonesia Bebas Dari Kutukan Kolonial?

Refleksi Kritis Atas MP3EI

Noer Fauzi Rachman \& Dian Yanuardy

Rontoknya Dominasi Negara di Tambang Batu Bara Ombilin Sawahlunto

Zaiyardam Zubir \& Zulqayyim

Protes Korban Bencana; Studi Konflik Penanggulangan Bencana di

Pasar Raya Padang

Firdaus

Peran Perempuan dalam Resolusi Konflik Rehabilitasi dan Rekonstruksi

Pasar Raya Padang

Ira Ariesta

Resolusi Konflik Berbasis Adat; Studi Resolusi Konflik Harta Pusaka Tinggi di Nagari Gantuang Ciri, Kab. Solok, Sumatera Barat

Yuhelna

Nelayan Vs Rentenir; Studi Ketergantungan Nelayan terhadap Rentenir pada Masyarakat Pesisir

Delmira Syafrini .

Profil Penulis. 



\title{
PROTES KORBAN BENCANA Studi Konflik Penanggulangan Bencana di Pasar Raya Padang ${ }^{1}$
}

\author{
Firdaus \\ (Dosen Program Studi Pendidikan Sosiologi STKIP PGRI Sumbar) \\ 一非—
}

\begin{abstract}
In a lot of case, disaster is not only cause victims and physical damage but also having an affect on social structure. Earthquake on Sumbar at 2009 is not an exception, the earthquake have a wide impact on Padang society structure. The relation between government and citizen in the process of economic infrastructure rehabilitation and reconstruction after earthquake at Pasar Raya is one of the impact. The process of economic infrastructure rehabilitation and reconstruction at Pasar Raya Padang give birth to conflict between government and merchantmen, but the conflict doesn't stop there, the conflict also affecting the citizen of Padang. Conflict happened in the form of merchantmen refusal concerning government policy in the efforts of Pasar Raya rehabilation and reconstruction after earthquake. Merchantmen has done the refusal in various form. This paper discussed about background, form, pattern and refusal strategy of the victim to government in the process of Pasar Raya rehabilitation and reconstruction after earthquake.
\end{abstract}

Kata Kunci: Protes, Korban Bencana, Kebijakan, Rehabilitasi \& Rekonstruksi.

\section{Pendahuluan}

Bencana gempa 30 September 2009 yang berpusat di Padang Pariaman, meninggalkan catatan pilu bagi masyarakat Sumatera Barat. Kepiluan itu terutama dirasakan oleh masyarakat Kota Padang, Kota Pariaman, Kabupaten Padang Pariaman dan Kabupaten Agam. Gempa dengan

1. Tulisan ini disarikan dari laporan penelitian tentang konflik rehabilitasi dan rekonstruksi Pasar Raya Padang pasca bencana 2009 yang dibiayai oleh Yayasan Interseksi dan Hivos Pada tahun 2011 melalui Program Pelatihan Penelitian Demokrasi dan Diversitas Kultural Angkatan III tahun 2011. kekuatan 7,9 SR itu telah meluluhlantakkan sebagian bumi Minangkabau, menyisakan banyak luka dan kepedihan mendalam bagi kehidupan masyarakat. Luka dan kepedihan mereka rasakan karena sebagian dari mereka menjadi korban langsung keganasan bencana, sebagian lainnya harus merelakan kehilangan harta dan juga sanak sauadara. Data terakhir Satkorlak, korban bencana meninggal dunia mencapai 1.195 orang orang (Singgalang, 30 Oktober 2009), 2.902 orang luka berat dan ringan, 278.286 unit rumah 
mengalami kerusakan, mulai dari retak-retak hingga rata dengan tanah, 3.699 unit fasilitas umum tak jauh berbeda, ambruk dan sujud ke bumi (Harian Padang Ekspress, 15 Oktober 2009).

Di kota Padang penanggulangan bencana rehabilitasi dan rekonstruski ${ }^{2}$, tidak jauh berbeda dengan penanggulangan bencana lainnya di Indonesia, kekacauan dalam pendataan, pendistribusian bantuan yang tidak merata, hingga kebijakan dan pelaksanaan kegiatan rehabilitasi dan rekonstruksi. Kebijakan rehabilitasi dan rekonstruksi Pasar Raya Padang tidak jauh berbeda, bermasalah dan mendapat penentangan dari masyarakat korban bencana dalam bentuk protes. Protes kebijakan rehabilitasi dan rekonstruksi muncul karena proses dan dampak pelaksanaan kebijakan yang bermasalah.

Kebijakan rehabilitasi dan rekonstruksi Pasar Raya Padang sudah menuai masalah dan mendapat penolakan dari warga kota yang menjadi korban bencana sejak masa tanggap darurat. Penolakan kebijakan rehabilitasi dan rekonstruksi kemudian menuai konflik vertikal berkepanjangan antara masyarakat korban bencana dengan pemerintah. Konflik kemudian menjadi manifest dan melahirkan banyak protes dengan jumlah massa yang luas. Sebagai bentuk penolakan, protes dalam berbagai bentuk dan skala besar terus bereskalasi dan sampai menyeret konflik lama yang bersifat laten. Eskalasi konflik terus terjadi dan melahirkan puluhan demonstrasi menentang kebijakan penanggulangan bencana yang terutama dimotori oleh konflik rehabilitasi dan rekonstruksi Pasar Raya Padang.

2. UU No. 24 Tahun 2007 Tentang Penanggulangan Bencana menyebutkan tiga tahap dalam penanggulangan bencana. Pertama adalah tahapan Mitigasi, yaitu serangkaian upaya untuk mengurangi risiko bencana, baik melalui pembangunan fisik maupun penyadaran dan peningkatan kemampuan menghadapi ancaman bencana. Kedua tahapan tanggap darurat yaitu serangkaian kegiatan yang dilakukan dengan segera pada saat kejadian bencana untuk menangani dampak buruk yang ditimbulkan, yang meliputi kegiatan penyelamatan dan evakuasi korban, harta benda, pemenuhan kebutuhan dasar, pelindungan, pengurusan pengungsi, penyelamatan, serta pemulihan prasarana dan sarana. Ketiga tahapan rehabilitasi dan rekonstruksi yang secara umum merupakan masa pemulihan pasca bencana setelah masa tanggap darurat berakhir (Konsideran UU RI No. 24 Tahun 2007 Tentang Penanggulangan Bencana).
Tidak hanya sampai di situ, protes juga menyeret masalah lain yang berkaitan dengan penanggulangan bencana. Isu bencana terus menggelinding hingga ke bantuan bencana gempa tahun 2007 yang belum dicairkan oleh Pemko Padang sampai bencana tahun 2009. Korban bencana tahun 2007 yang sampai bencana 2009 belum menerima bantuan dari Pemko Padang turut menjadi bagian dari aksi protes korban bencana Pasar Raya Padang. Dalam aksi-aksi demonstrasi, mereka manjadi element aksi yang memprotes masalah pengelolaan bencana, terutama pencairan bantuan gempa 2007.

Protes sebagai salah satu bentuk perlawanan terus bereskalasi dan melibatkan banyak kelompok korban pembangunan kota Padang secara umum. Protes kemudian juga merembes dan menyeret kasus-kasus lain yang mengendap. kasus korupsi Teluk Siriah, kasus pembangunan terminal Gon Hoat korban, kasus pembangunan Terminal Lintas yang dihapus dan dijadikan Plaza, korban pembangunan Terminal Gon Hoat menjadi Sentral Pasar Raya (SPR) hingga pembangunan-pembangunan kota lainnya muncul dalam aksi yang sama dan menjadi bagian dari barisan protes bersama korban bencana. Tulisan ini berusaha mengungkap alasan di balik konflik penanggulangan bencana Pasar Raya Padang terus bereskalasi dan belum menemukan solusi/jalan keluar yang sesuai dengan kebutuhan korban bencana Pasar Raya. Tulisan ini terutama akan banyak mengulas, pertama faktor yang mendorong munculnya konflik dan protes dalam penanggulangan bencana di Pasar Raya Padang dan kedua pola dan bentuk protes yang dilakukan oleh korban bencana terhadap kebijakan penanggulangan bencana di Pasar Raya Padang.

\section{Tinjauan Pustaka}

James. C Scott, dalam bukunya Weapon of the Weak: Everyday Forms Peasant Resistence (1976), mendeskripsikan bentuk-bentuk 
perlawanan yang dilakukan oleh masyarakat petani Sedeka di Malaysia. Dalam penelitiannya Scott menemukan beberapa bentuk perlawanan yang dilakukan oleh petani Sedeka terhadap kelompok-kelompok mapan yang mereka konstruksi sebagai biang dari ketidakadilan dan penindasan. Perlawanan yang dilakukan oleh petani Sedeka disebut Scott dengan perlawan "tanda-tanda kegiatan" yang sifatnya insidental bahkan efipenomenal. Secara praktis perlawanan tersebut berwujud dalam bentuk-bentuk yang diantaranya pertama, tidak terorganisir, tidak sistematis dan individual. Kedua bersifat untung-untungan dan "berpamrih" (nafsu akan kemudahan). Ketiga, tidak mempunyai akibat revolusioner. Keempat, dalam maksud dan logikanya mengandung arti penyesuain dengan sistem yang dominan. Sehingga perlawanan yang dimaksudkan di sini tidak perlawanan yang sesungguhnya yang berciri terorganisir, sistematif, kooperatif, berprinsip, berpamrih, mempunyai akibat revolusioner dan mengandung gagasan atau tujuan yang meniadakan dasar dari dominasi itu sendiri, akan tetapi perlawanan secara kucing-kucingan (Scott, 1993:305 dalam Taufik:2003).

Bagi Scott masyarakat tradisional mempunyai tata tertib moral yang tidak dapat dipisahkan dari masalah subsistensi. Tatanan sosial dari kehidupan petani telah menghasilkan sistem jaminan keamanan hidup internal yang secara normatif dapat ditegakkan untuk memenuhi semua orang desa. Kolonialisme telah mengukir eksploitasi tanpa batas yang dikenakan pada para petani sedemikian rupa sehingga terbentuklah diferensiasi sosial yang baru, dislokasi agraria, kemerosotan dari moral mengutamakan kebersamaan dan kapitalisme agraria yang rakus -kesemua ini sungguh mengancam keberlangsungan hidup petani. Scott selanjutnya menekankan moralitas dan kemarahan petani sebagai respon yang niscaya begitu adanya menghadapi hilangnya jaminan keamanan subsistensi minimum. Walhasil, pemberontakan petani pada dasarnya bersifat dari keinginan konservatif dan restoratif (mempertahankan dan atau mengembalikan yang terdahulu) (Fauzi, 2005:22-23).

Perlawanan yang dilakukan pedagang korban bencana di Kota Padang memiliki karakteristik berbeda dengan perlawanan yang dilakukan petani di Sedeka. Jika perlawanan yang dilakukan oleh petani Sedeka adalah perlawanan secara kucing-kucingan, maka perlawanan yang dilakukan oleh masyarakat kota padang adalah perlawanan terbuka. Dimana puluhan demonstrasi telah berlangsung dilakukan oleh masyarakat kota Padang secara terorganisir. Perlawanan yang dilancarkan merupakan tindakan sadar sebagai manifestasi rasionalitas karena perlawanan yang dilakukan masyarakat kota Padang merupakan pilihan sadar, atas refleksi yang mendalam serta mempunyai tujuan dengan mempergunakan alat-alat untuk mencapai tujuan tersebut.

Selain apa yang ditulis oleh Scott, studi tentang perlawanan masyarakat sipil juga pernah dilakukan oleh M. Taufik dalam tesis Sosiologi Pascasarjana UGM. Dalam tesis ini, M. Taufik mengulas tentang perlawanan pedagang kaki lima Minangkabau di kota Jogjakarta terhadap kebijakan penertiban mereka sebagai pedagang kaki lima. Taufik mengulas bahwa secara nyata perlawanan yang mereka lakukan terhadap negara lebih banyak bersifat tersembunyi dan diam-diam. Karena didasari oleh kesadaran kognitif dan pengetahuan mereka yang bersendi kepada kepatutan yang sudah hidup dan tertuang dalam pepatah, petitih dan pengajaranpengajaran yang terdapat dalam masyarakat Minangkabau. Mereka sangat menghindari perlawanan dalam bentuk fisik. Karena difahami perlawanan bentuk fisik hanya perlawanan yang dilakukan oleh binatang dan itu tidak akan menyelesaikan permasalahan, malahan akan lebih memperumit dan membesarkan masalah. Mereka akan memandang hormat kekuasaan atau pemimpin manakala pemimpin melambangkan 
keadilan, kesejahteraan. Manakala tidak, mereka akan enggan dan menolak setiap perintah yang disampaikan bahkan cemoohan akan dilontarkan pada setiap kesempatan. Penolakan tentu saja tidak dengan kekuatan fisik, namun dengan cara "bermain-main": kucing-kucingan. Mereka akan tetap saja mengikuti kemauan kekuasaan tetapi di belakang mereka akan tetap melakukan keinginan mereka (Taufik, 2003:287).

Studi Scott lebih menekankan pada perlawanan petani, sementara studi Taufik lebih menekankan pada perlawana PKL Minangkabau terhadap pemerintah. Dua studi ini memiliki kemiripan, yaitu perlawanan yang dilakukan secara diam-diam dan kucing-kucingan. Kontras berbeda dengan perlawanan yang dilakukan oleh masyarakat kota Padang yang secara terbuka. Di sini letak perbedaan tulisan ini. Perlawanan yang dilakukan oleh korban bencana Kota Padang dilakukan secara terbuka dan bahkan bersifat frontal. Head to head dengan pemerintah Kota dan bahkan dengan lembaga-lembaga pemerintahan yang terkait dengan rahabilitasi dan rekonstruksi pasca bencana. Bahkan, aksi demonstrasi yang dilakukan oleh pedagang sudah bersifat anarkhis dengan merusak fasilitas publik yang ada, kata-kata kasar dan carut-marut terhadap Pemko Padang (Walikota) tak jarang keluar dari mulut para demonstran dalam setiap aksi demonstrasi yang dilakukan.

Dalam tulisan ini beberapa konsep yang digunakan perlu dibatasi untuk menyamakan pemahaman terhadap konsep. Karena tulisan ini merupakan uraian tentang protes perlawanan korban bencana atas kebijakan rehabilitasi dan rekonstruksi pasca bencana, maka penggnaan konsep dalam penulisan ini akan banyak mengacu pada konsep yang ada dalam Undang-Undang No. 24 tahun 2007 tentang Penanggulangan Bencana. Beberapa konsep yang diambil dari UU ini adalah:

1. Rehabilitasi dan rekonstruksi, merupakan kegiatan dalam rangka pemulihan kondisi wilayah korban bencana dari dampak bencana.
2. Rehabilitasi adalah perbaikan dan pemulihan semua aspek pelayanan publik atau masyarakat sampai tingkat yang memadai pada wilayah pascabencana dengan sasaran utama untuk normalisasi atau berjalannya secara wajar semua aspek pemerintahan dan kehidupan masyarakat pada wilayah pascabencana.

3. Rekonstruksi adalah pembangunan kembali semua prasarana dan sarana, kelembagaan pada wilayah pasca bencana, baik pada tingkat pemerintahan maupun masyarakat dengan sasaran utama tumbuh dan berkembangnya kegiatan perekonomian, sosial dan budaya, tegaknya hukum dan ketertiban, dan bangkitnya peran serta masyarakat dalam segala aspek kehidupan bermasyarakat pada wilayah pascabencana.

4. Korban bencana adalah orang atau sekelompok orang yang menderita atau meninggal dunia akibat bencana.

Dalam penulisan ini, rehabilitasi yang dimaksud adalah perbaikan dan pemulihan Pasar Raya pasca gempa Sumatera Barat 30 September 2009. Kemudian rekonstruksi adalah pembangunan kembali fasilitas Pasar Raya pasca gempa Sumatera Barat 30 September 2009. Korban adalah korban bencana 30 September 2009 yang terdiri dari korban langsung dan korban tidak langsung. Korban langsung adalah pedagang yang menderita karena bencana gempa yang disebabkan oleh kerusakan pada tempat mereka berdagang. Korban bencana yang bukan pedagang dan tidak mengalami kerusakan tempat berdagang di Pasar Raya Padang -seperti korban bencana yang rumahnya roboh karena bencana gempa atau tempat berdagangnya rusak tetapi tidak di Pasar Raya Padang- tidak termasuk dalam konsep korban bencana yang dimaksud dalam tulisan. Korban tidak langsung adalah korban yang menderita karena dampak kebijakan dan pelaksanaan rehabilitasi dan rekonstruksi sarana dan pra sarana fisik Pasar Raya Padang. 


\section{Metode Penelitian}

Artikel ini merupakan laporan penelitian yang dilaksanakan pada tahun 2011 dengan tajuk yang sama yang dibiayai oleh Yayasan Interseksi dan Hivos melalui program pelatihan penelitian tahun angkatan III. Penelitian dilakukan di Kota Padang dengan metode kualitatif. Fokus penelitian dilakukan di Pasar Raya yang merupakan kasus dalam penelitian ini. Penelitian dilakukan dalam rentang waktu Maret-April 2011 dengan tetap mengikuti agenda-agenda protes dan pertemuanpertemuan pedagang bersama kuasa hukum dalam merancang dan merumuskan kegiatan dalam melakukan penolakan terhadap kebijakan rehabilitasi dan rekonstruksi Pasar Raya. Dalam rentang waktu tersebut wawancara dengan pedagang dan pengamatan lapangan dilakukan dilakukan secara intensif.

Data penelitian yang disajikan dalam tulisan ini diperoleh melalui wawancara dan interview dengan pedagang korban bencana yang melakukan protes terhadap kebijakan penaggulangan bencana. Selain itu, data juga diperoleh melalui keterlibatan langsung peneliti dalam agenda dan kegiatan protes yang dilakukan oleh korban bencana, baik dalam bentuk pertemuan-pertemuan, lobby dan demonstrasi. Data ini juga diperoleh dari kliping koran, surat-surat pedagang melalui kuasa hukum (PBHI Sumbar) pada lembaga-lembaga yang berhubungan dengan penanggulangan bencana Pasar Raya Padang.

\section{Bencana: Geneologi Protes?}

Sebelum memulai tulisan tentang faktor yang melatarbelakangi protes korban bencana di Pasar Raya, penting untuk mengulas secara singkat cerita bencana gempa yang menelan banyak korban di Sumatera Barat dan sekaligus menjadi cikal bakal lahirnya konflik di Pasar Raya Padang. Penulisan kronologis ini dimaksudkan untuk memberikan sedikit gambaran tentang peristiwa yang secara khusus sangat berpengaruh terhadap kondisi sosial, ekonomi dan budaya masyarakat Kota Padang pasca bencana, terutama di Pasar Raya Padang.

Goncangan gempa dengan kekuatan 7.9 pada skala richter tiba-tiba menghentakkan ketenangan masyarakat yang sebagian besar sedang mengakhiri aktifitas harian. Orangorang panik dan berhamburan menyelamatkan diri keluar bangunan yang berguncang hebat. Ketakutan terhadap ancaman runtuhnya bangunan menjadi pemicu kepanikan. Kepanikan terutama bersumber dari rasa takut masyarakat terhadap isu tsunami yang sewaktu-waktu mengancam pantai Sumatera. Dalam pengetahuan masyarakat, sudah umum bahwa Sumatera Barat adalah wilayah yang paling rawan Tsunami karena berada di atas patahan Semangka Sumatera. Ketakutan tersebut yang mendorong ribuan orang mengungsikan diri dan keluarga mereka ke arah timur kota Padang yang merupakan bagian tinggi kota sebagai tempat evakuasi tsunami.

Isu tsunami Sumatera Barat terutama kota Padang dan Padang Pariaman sebagai daerah yang paling rawan sudah mulai beredar di kalangan masyarakat sejak gempa dan tsunami di Aceh tahun 2004. Pasca gempa dan Tsunami Aceh, isu tsunami begitu menjadi "hantu" bagi masyarakat kota Padang. Bahkan, beberapa kali warga kota Padang mengungsi tengah malam karena isu bencana tsunami ${ }^{3 .}$ Sebagai daerah yang dekat dengan pantai, pusat kota Padang yang sekaligus berdekatan dengan pusat ekonomi kota hanya berjarak $\pm 1 \mathrm{~km}$ dari bibir pantai, ketakutan terhadap ancaman tsunami ikut menimbulkan kepanikan warga yang sedang berada di Pasar Raya saat gempa 30 September 2009 mengguncang.

3. Tahun 2005, lewat tengah malam hingga dini hari warga Kota Padang berbondong-bondong ke arah timur kota -terutama ke arah Kec. Lubug Begalung, Kec. Pauah dan kec. Kuranji yang merupakan kawan tinggi kota- untuk menyelamatkan diri karena isu ancaman tsunami. Padahal, malam itu tidak terjadi bencana gempa, namun karena rasa takut, warga rela berjalan kaki belasan kilometer membawa keluarga dan barang berharga -seperti ayam, kambing, sapi dan lain sebagainya- untuk menyelamatkan diri ke tempat yang lebih tinggi. Diantara mereka bahkan ada yang berpakaian seadanya (pengalaman penulis). 
Secara fisik, dampak langsung bencana gempa dengan kekuatan 7.9 SR mengakibatkan robohnya beberapa bangunan pasar di Pasar Raya Padang yang merupakan sentra ekonomi kota. Bangunan fisik pasar yang ambruk antara lain adalah bangunan inpres I lantai II, bangunan Inpres II lantai II yang merupakan pasar tradisional yang menyediakan kebutuhan harian (sembako). Bangunan lainnya, mengalami kerusakan parah seperti Sentral Pasar Raya (Pasar Grosir) yang kemudian dirobohkan karena dinyatakan tidak layak, bangunan Fase VII lantai II dan III dan bangunan-bangunan lainnya juga mengalami kerusakan parah.

Untuk pasar Inpres, lebih kurang satu jam pasca gempa, pedagang dan masyarakat lain yang masih berada di sekitaran pasar melihat asap mengepul dari bangunan Inpres I yang diduga terjadi kebakaran setelah gempa. Perkiraan pedagang kebakaran disebabkan oleh ledakan kompor gas milik pedagang yang meledak karena ditimpa reruntuhan bangunan. Nyala api yang membakar Inpres I terus membesar, dan penulis yang pada malam bencana berjalan di sekitaran pasar masih melihat asap mengepul hingga dinihari di bawah hujan yang turun cukup deras. Menjelang subuh penulis masih melihat asap mengepul sangat besar di bangunan Inpres $I^{4}$.

Kebakaran yang terjadi di bangunan Inpres I tidak segera dipadamkan oleh petugas Pemadam Kebakaran kota Padang. Bahkan, kebakaran di bangunan Inpres I bertahan sampai hari ke 30 pasca bencana, padahal mobil pemadam kebakaran selalu tersedia persis di samping bangunan Inpres I, tepatnya di belakang bangunan Balaikota Padang. Kebakaran yang bertahan hingga 30 hari, menurut pedagang menjadi penyebab robohnya bangunan inpres I lantai I yang menopang sisa reruntuhan lantai

4. Saat malam kebakaran, penulis sebenarnya tidak tahu dengan persis bahwa yang terbakar adalah bangunan Inpres I. Diskusi dengan temanteman yang ada di pasar malam itu, kami menduga yang terbakar adalah balaikota yang berada di depan Inpres I. Penulis baru tahu bahwa yang terbakar adalah bangunan Inpres I hari ke-dua pasca bancana berdasarkan informasi dari teman-teman (media cetak baru terbit hari ke lima pasca bencana).
II sehingga bangunan Inpres I roboh secara keseluruhan. Api yang terus menyala dan membakar bangunan menyebabkan rapuhnya struktur bangunan Inpres I lantai I karena tidak kuat menopang sisa reruntuhan bangunan lantai II dan akhirnya roboh dan rata dengan tanah.

Menurut pemerintah Kota Padang, bangunan Inpres I roboh karena beberapa kali dogoncang gempa susulan dengan kekuatan bervariasi yang terjadi setelah gempa berkekuatan 7.9 SR. Selain roboh, Inpres I juga menelan korban nyawa sebanyak 38 orang $^{\square}$ (11 orang pedagang dan 27 orang pengunjung). Dalam masa tanggap darurat pasca bencana, kondisi pasar yang roboh tidak terlalu menjadi perhatian publik.

Di hari ketiga pasca bencana gempa, dalam kondisi kota seperti kota mati, sebagian pedagang Pasar Raya Padang mulai bangkit dan mulai membersihkan kios, los, toko dan barang-barang dagangan mereka untuk memulai aktifitas perdagangan. Di pasar Inpres II lantai I, inpres III dan inpres IV yang merupakan pasar tradisional penyedia kebutuhan harian warga kota, aktifitas jual beli di Pasar mulai normal pada minggu kedua pasca bencana. Semakin hari, geliat ekonomi pasar mulai tumbuh dan aktifitas jual beli pedagang di minggu ketiga sudah kembali normal seperti sebelum bencana. Di Inpres I yang roboh, beberapa pedagang mulai membersihkan tempat berdagang di sekitaran reruntuhan bangunan dan kembali memulai perdagangan dengan sisa modal yang tersisa. Pasar dan aktifitas ekonomi mulai kembali stabil dan normal sementara evakuasi korban di tempat lain masih berlangsung.

\section{Kebijakan; Faktor Penyebab Protes}

Gempa Sumbar ditetapkan oleh pemerintah sebagai bencana daerah dengan masa tanggap darurat selama 2 bulan terhitung semenjak 1 Oktober 2009 hingga 30 November 2009. Dalam masa tanggap darurat, perhatian pemerintah, masyarakat, lembaga-lembaga 
sosial seperti NGO, Ormas dan sebagainya lebih tertuju pada kegiatan-kegiatan tanggap darurat. Kegiatan tanggap darurat lebih terfokus pada dua hal. Pertama kegiatan penyelamatan dan evakuasi korban bencana yang tertimbun di reruntuhan bangunan. Untuk kota Padang, kegiatan penyelamatan dan evakuasi korban terutama di reruntuhan bangunan-bangunan dimana banyak korban tertimbun. Kegiatan penyelamatan dan advokasi yang tersorot publik terutama di Hotel Ambacang, Kampus ABA dan kampus LBA-LIA. Kedua kegiatan distribusi bantuan berupa makanan, pakaian, obat-obatan, tenda dan kebutuhan-kebutuhan masa tanggap darurat.

Kegiatan penanggulangan bencana tanggap darurat -penyelamatan dan evakuasi korban- di bangunan Inpres I yang roboh dengan jumlah korban jiwa 38 orang juga berlangsung sama seperti kegiatan tanggap darurat di lokasi lain. dalam proses evakuasi korban, pedagang pasar terlibat aktif menyelamatkan dan mengeluarkan korban yang tertimbun di bangunan Inpres I. Kerjasama antara pemerintah kota dengan pedagang berjalan baik dengan saling membantu. Kerjasama terjadi secara alamiah dengan semangat yang sama, semangat kemanusiaan dalam menyelamatkan korban bencana.

Kerjasama antara pemerintah dan pedagang Pasar Raya mulai mengalami keretakan setelah lahir kebijakan penanggulangan bencana pasca avakuasi korban. Pemerintah kota, dalam masa tanggap darurat mengeluarkan beberapa kebijakan yang berpotensi merugikan pedagang. Kebijakan tersebut dibuat tanpa melibatkan partisipasi pedagang. Setidaknya, ada tiga kebijakan yang menjadi faktor penyebab munculnya konflik antara masyarakat dengan Pemko Padang. Pertama kebijakan pembanguna kios darurat pada masa tanggap darurat yang dianggap merugikan pedagang. Kedua kebijakan pembangunan ulang pasar Inpres I, II, III dan IV yang dianggap oleh pedagang tidak sesuai dengan kebutuhan pedagang dan keluar dari konteks penanggulangan bencana. Ketiga adalah pembangunan pertokoan Fase VII lantai II dan III yang mengharuskan pengosongan pada lantai I. Untuk lebih rinci, akan diurai satu per satu kebijakan pemicu protes korban bencana.

\section{a. Pembangunan Kios Darurat}

Dalam masa tanggap darurat, pada hari ke 23 pasca bencana pemerintah kota Padang memulai pembangunan kios darurat di Pasar Raya Padang dengan memasok bahan bangunan pada tanggal 22 oktober 2009 malam. Pembangunan tersebut terjadi secara tiba-tiba dan pelaksanaannya melibatkan TNI Yon Zikon 13/kf dengan nilai kontrak 2,4 milyar rupiah dan dimulai di jalan Pasar Baru Pasar Raya, persis di depan bangunan Inpres III yang tidak terkena dampak bencana. Pembangunan kios darurat, oleh Pemko dimaksudkan untuk memacu pertumbuhan ekonomi pasca bencana. Pemerintak Kota berencana membangun 1.100 unit kios di sepanjang jalan Pasar Baru, jalan Sandang Pangan dan jalan Pasar Raya yang merupakan jalan utama keluar masuk ke Inpres II, III dan IV.

Dalam pembangunan kios darurat, ada tiga hal yang menjadi alasan penolakan oleh pedagang. Pertama pembangunan kios darurat dilakukan oleh pemko Padang secara tiba-tiba tanpa sebelumnya ada sosialisasi dengan pedagang. Hal tersebut dengan alasan pembangunan kios darurat adalah penanggulangan bencana, sementara aturan penanggulangan bencana sesuai dengan amanah undang-undang harus dilakukan secara partisipatif. Kedua jumlah kios yang dibangun oleh Pemko Padang melebihi kapasitas kebutuhan untuk relokasi korban bencana. Jumlah pedagang yang akan direlokasi dari bangunan inpres yang runtuh karena bencana menurut pedagang hanya berjumlah lebih kurang 445 orang. 
Sementara bengunan kios darurat yang dibangun oleh Pemko padang 1.100 unit. Kelebihan kapasitas pembangunan kios darurat dicurigai oleh pedagang sebagai strategi mematikan aktifitas ekonomi di Inpres II, III dan IV, Petak Batu Bagonjong, Petak buah dan kelompok pedagang lainnya. Ketiga pembangunan kios darurat yang dibangun di sepanjang jalan Pasar Baru, jalan Sandang Pangan dan jalan Pasar Raya berdampak pada akses pembeli untuk menuju dan keluar dari kios pedagang di Inpres II, III dan IV. Tertutupnya akses pembeli, mengakibatkan turunnya jual beli pedagang yang berdampak terhadap penghasilan mereka.

Ketiga alasan di atas menjadi alasan utama pedagang melakukan penolakan terhadap pembanguna kios darurat. Dan ketiga alasan tersebut yang menjadi alasan awal protes oleh pedagang Pasar Raya Padang dengan melakukan aksi demonstrasi di kantor DPRD Kota Padang pada tanggal 23 Oktober 2009. Aksi demonstrasi dilakuakan oleh pedagang kaki lima dan pedagang ayam yang merupakan korban bencana di Inpres I yang roboh. Penolakan tersebut oleh Pemko Padang tidak direspon dengan tetap melanjutkan pembangunan kios melibatkan TNI Yon Zikon 13/kf.

\section{b. Rekonstruksi Inpres II, III \& IV}

Secara geneologis, pembangunan kios darurat merupakan pemicu awal protes korban bencana. Protes pedagang yang menuntut pembongkaran kios darurat dan tidak adanya respon dari Pemko terus bertahan. Dalam situasi yang tidak kondusif tersebut, pemerintah kota kembali mengeluarkan kebijakan yang baru melalui dinas pasar. Kepala Dinas Pasar melalui pemberitahuan tertulis tanggal 10 November 2009, meminta pedagang Inpres II, III dan IV untuk mengosongkan petak toko/kios untuk pindah ke Kios dan Los dengan batas waktu sampai tanggal 13 November 2009. Apa bila sampai batas waktu itu tidak dilakukan, Dinas Pasar akan melakukan upaya paksa pengosongan. Pemberitahuan tersebut disampaikan melalui surat Nomor : 900.1699 . XI/PS-09 tanggal 10 November 2009.

Pemberitahuan yang disampaikan oleh Dinas Pasar Kota Padang untuk mengosongkan petak toko/kios menyadarkan pedagang bahwa Pemko Padang juga akan merekonstruksi bangunan Inpres II, III dan IV yang mereka yakini masih layak pakai berdasarkan hasil penelitian yang dilakukan oleh Tim Teknis Gabungan Pengusaha Konsumsi Indonesia (Gapeksindo) Kota Padang. Menurut Tim Teknis Gapeksindo bangunan Inpres II lantai I dan bangunan Inpres III lantai IV masih layak huni. Perintah mengosongkan Inpres II, III dan IV ditolak pedagang Inpres II lantai I dan Pedagang Inpres III lantai I dan II karena pemberitaanpemberitaan media lokal mengatakan bahwa gedung Inpres II, III, dan IV akan dibongkar kemudian akan dibangun oleh investor dari Malaysia dan Cina. Menurut pedagang, Inpres II, III dan IV masih layak huni dan tidak perlu dirobohkan, tetapi cukup direhabilitasi saja bagian yang rusak.

Penolakan oleh pedagang dilakukan melalui aksi damai pada tanggal 11 November 2009, dengan melibatkan 2000 pedagang ke DPRD Kota Padang. Hasil aksi tersebut melahirkan Rekomendasi DPRD Kota Padang Nomor : 175/057/DPRD-Pdg/2009, dengan inti surat meminta Pemko Padang agar membongkar Kios dan Los Darurat dan membicarakan dengan duduk bersama antara Pemko, DPRD dan Perwakilan Pedagang dalam pelaksanaan Rekomendasi. Namun rekomendasi yang dikeluarkan oleh DPRD tidak mendapat perhatian dari pemko Padang dengan tetap tidak membongkar kios darurat. 
Perintah untuk mengosongkan Inpres II, III dan IV berlanjut dengan upaya pemaksaan sebagian kecil Pedagang Inpres I dengan pengawalan ketat Anggota Satpol PP Kota Padang dan Anggota Brimob Polda Sumbar untuk memasuki dan menempati Kios dan Los Darurat. Selain itu Walikota Padang juga mengeluarkan ancaman akan mempidanakan oknum yang melakukan pembongkaran paksa Kios dan Los tersebut. Upaya pemaksaan untuk pengosongan kemudian juga berlanjut dengan pemutusan hubungan listrik di Inpres II dan III oleh PLN yang diperintahkan oleh Pemko Padang.

\section{c. Kebijakan Pembangunan Pertokoan Fase VII Lantai II dan III}

Sebelum pedagang Inpres II, III dan IV diminta mengosongkan petak toko/los, pedagang pertokoan fase VII sudah diminta mengosongkan toko mereka 2 minggu sebelumnya melalui surat pemberitahuan dari Dinas Pasar Kota Padang tanggal 28 Oktober 2009. Pemberitahuan tersebut disampaikan oleh Dinas Pasar karena akan dilakukan perbaikan pada lantai II dan III. Perintah pengosongan lantai I ditolak oleh pedagang pertokoan fase VII karena menurut mereka, perbaikan pada lantai II dan lantai III dapat dilakukan dengan dengan tanpa mengosongkan lantai I.

Penolakan yang dilakukan oleh pedagang pertokoan fase VII didasarkan pada hasil kajian kelayakan bangunan yang dilakukan oleh Institut Tekhnologi Padang (ITP) yang telah melakukan pengujian kelayakan bangunan terhadap pertokoan fase VII. Menurut rekomendasi yang diberikan oleh ITP, struktur bangunan pertokoan fase VII masih layak pakai dan tidak harus dilakukan pembongkaran. Kemudian untuk melakukan perbaikan pada lantai II dan III tidak harus melakukan pengosongan pedagang pada lantai I.
Meskipun pedagang memiliki argumentasi akademik dalam melakukan penolakan terhadap pengosongan dengan menggandeng ITP untuk melakukan kajian teknis, namun fihak pelaksana pembangunan pada lantai II dan III tetap ingin pedagang pada lantai I harus dikosongkan. Argumentasi pelaksana, tidak dikosongkannya bangunan pada lantai I menghambat pekerjaan pembangunan pada lantai II dan III. Dan hal inilah yang melahirkan konflik dan protes dari pedagang pertokoan fase VII. Pedagang menilai pelaksana pembangunan tidak profesional. Penilaian tersebut didasarkan pada pengalaman sebelumnya, dimana pembangunan yang dilakukan pada lantai II dan III tidak dengan mengosongkan pedagang pada lantai I.

\section{Pola, Bentuk dan Strategi Protes}

Meminjam istilah Sztompka (2004:235) bahwa gerakan kolektif yang diorganisir secara longgar, tanpa cara terlembaga untuk menghasilkan perubahan dalam masyarakat adalah perubahan sosial, maka gerakan kolektif dalam bentuk protes yang dilakukan oleh pedagang korban bencana di Pasar Raya Padang menjadi bagian dari gerakan sosial masyarakat sipil yang dibidangi oleh berbagai kalangan. Sebagai sebuah gerakan sosial, protes yang dilakukan oleh korban bencana memiliki pola dan bentuk-bentuk tertentu sesuai dengan situasi dan perkembangan yang terjadi di lingkungan mana proses sosial sedang berlangsung.

Seperti dikatakan oleh Barker dan Lavellete (dalam Afrizal, 2006:42), strategistrategi yang diterapkan oleh orang dalam gerakan sosial berdasarkan analisis situasi dan merupakan 'proses interaktif dan relational'. Apa yang dilakukan oleh pelaku gerakan sosial merupakan antisipasinya terhadap apa yang dilakukan oleh orang lain dan tanggapannya terhadap apa yang telah dan sedang dilakukan 
oleh orang lain. Reaksi yang diberikan oleh pedagang korban bencana terhadap kebijakan rehabilitasi dan rekonstruksi Pasar Raya Padang pasca bencana menjadi respon pedagang korban bencana terhadap apa yang dilakukan oleh Pemko Padang dalam proses rehabilitasi dan rekonstruksi Pasar Raya Padang.

Sebagai bentuk respon terhadap kebijakan pemerintah Kota Padang, pola dan bentuk protes yang dilakukan oleh korban bencana bervariasi seirama dengan respon pemko terhadap reaksi mereka. Irama protes yang berjalan sama dengan respon yang diberikan oleh Pemko Padang terhadap protes-protes yang dilakukan oleh masyarakat korban bencana. Mengikuti respon pemerintah Kota terhadap reaksi pedagang dalam menolak kebijakan rehabilitasi dan rekonstruksi pasar, pola-pola dan strategi yang dilakukan oleh pedagang sangat beragam. Beberapa bentuk dan strategi yang dilakukan oleh pedagang antara lain melalui demonstrasi, lobby, hearing dengan legislatif, strategi organisasi, menggalang dukungan dan terakhir menggunakan kuasa hukum.

Demonstrasi merupakan bentuk strategi protes awal yang dilakukan oleh pedagang dalam menolak pembangunan kios darurat yang dinilai over kapasitas. Demonstrasidemonstrasi berikutnya juga dilakuan oleh pedagang dalam menolak kebijakan-kebijakan baru yang dikeluarkan oleh Pemko Padang. Selain itu demonstrasi juga dilakukan oleh pedagang dalam menyikapi respon pemerintah yang dinilai oleh mereka tidak aspiratif. Dengan penilaian tersebut, gelombang aksi unjuk rasa semakin membesar dan terus dilakukan oleh pedagang bersamaan dengan tidak diresponnya tuntutan mereka oleh Pemko Padang.

Lobby yang dilakukan oleh pedagang korban bencana Pasar Raya Padang mengikuti alur demonstrasi dan unjuk rasa. Lobby dilakukan ke instansi-instansi yang berhubungan dengan isu yang mereka usung mengiringi aksi unjuk rasa yang dilakukan. Lobby pertama yang dilakukan oleh pedagang bersamaan dengan tidak adanya respon dari Pemko Padang terhadap tuntutan mereka dalam demonstrasi awal yang dilakukan. Pedagang mengadukan sikap dan tindakan Walikota Padang yang mengabaikan aspirasi mereka menolak pembangunan kios darurat. Lobby tidak hanya sebatas dangan DPRD Kota, tetapi juga dilakukan dengan DPRD Propinsi, Gubernur, Badan Pemeriksa Keuangan dan Pembangunan dan ormas-ormas lain.

Strategi organisasi digunakan oleh pedagang untuk memperkuat barisan dalam melakukan penolakan atas kebijakan pembangunan ulang Pasar Raya Padang. Dalam upaya memperkuat barisan, pedagang mengukuhkan organisasi-organisai lama yang tidak eksis, membentuk organisasi-organisasi baru sesuai dengan karakteristik jenis dagangan dan atau tempat berdagang. Dengan menguatkan organisasi lama dan membentuk baru, kekuatan pedagang dalam melakukan protes semakin kuat dan terorganisir dengan baik. Aksi protes kemudian berkembang ke massa yang lebih luas. Dari strategi organisasi ini kemudian muncul wadah bersama pedagang pasar dan kelompokkelompok lain yang juga merasa dirugikan oleh pembangunan di Kota Padang. Wadah bersama tersebut terbentuk dalam suatu forum yang bernama Forum Warga Kota (FWK).

Secara umum dalam menolak kebijakan rehabilitasi dan rekonstruksi pasar, terdapat tiga periode dalam gerakan pedagang. Pertama, periode gerakan kelompok pedagang yang terdiri dari organisasi pedagang berdasarkan kelompok yang kemudian membangun aliansi yang mereka namakan dengan Aliansi Pedagang Pasar Raya (APPR) Padang. Kedua, periode gerakan secara terorganisir di bawah organisasi Forum Warga Kota (FWK). Ketiga, periode gerakan hukum bersama Perhimpunan Bantuan Hukum dan Hak Asasi Manusia Indonesia (PBHI) Sumatera Barat. Pola dan strategi gerakan yang dilakukan oleh pedagang memiliki karakter yang berbeda 
pada masing-masing periode. Perbedaan yang mencolok terutama terlihat dari strategi yang digunakan.

\section{a. Bentuk dan Strategi Bersama APPR}

Sadar dengan kekuatan yang dihadapi dengan mengikuti respon pemerintah dan berita tentang pembangunan yang melibatkan investor, pedagang menyatukan kekuatan yang ada dalam bentuk aliansi bersama yang diberi nama Aliansi Pedagang Pasar Raya (APPR) Padang. Bersama aliansi kemudian gerakan-gerakan perlawanan dalam bentuk unjuk rasa terus dilakukan mengikuti respon yang diberikan oleh pemerintah terhadap tuntutan mereka. Bersama APPR unjuk rasa terus berkembang luas dan diikuti oleh massa yang banyak. Dalam setiap aksi unjuk rasa, pedagang korban bencana membangun dialog dengan pihak legislatif.

Strategi gerakan protes yang dilakukan oleh pedagang pasar bersama APPR lebih dominan unjuk rasa dan demonstrasi dengan mendatangi lembaga legislatif untuk menyampaikan aspirasi mereka. Dalam setiap demonstrasi dan unjuk rasa yang dilakukan, pedagang juga melakukan dialog untuk mendapatkan dukungan dari legsislatif dalam penolakan mereka terhadap kebijakan pembangunan yang dikeluarkan oleh Pemko Padang. Hasil dialog yang dilakukan dengan DPRD menghasilkan beberapa rekomendasi. Antara lain rekomendasi untuk menghentikan pembangunan kios darurat, rekomendasi untuk membongkar kios darurat dan rekomendasi kepada Pemko untuk membahas secara bersama-sama pembangunan kembali Pasar Raya Pasca bencana.

\section{b. Bentuk dan Strategi Bersama FWK}

Pola umum dan pendekatan gerakan perlawanan dalam bentuk protes dilakukan oleh pedagang bersama FWK hampir sama dengan gerakan yang dilakukan bersama
APPR. Namun perbedaan spesifik gerakan yang dilakukan bersama FWK lebih pada adanya upaya-upaya desakan melalui suratsurat dan dokumen-dokumen pernyataan yang dilayangkan ke lembaga-lembaga pemerintahan yang berhubungan dengan penanggulangan bencana terkait dengan penanggulangan bencana kota Padang. Selain itu, gerakan protes FWK tidak hanya sebatas gerakan penolakan terhadap pembanguna kios darurat. Namun isu sudah diperluas ke tuntutan lain. Pada tahapan awal, ada tiga poin tuntutan gerakan masyarakat bersama FWK, yaitu pembongkaran kios darurat, pembangunan terminal kota dan pencairan bantuan bencana 2007.

Menjadi bagian dari strategi perlawanan korban bencana terhadap kebijakan rehabilitasi dan rekonstruksi Pasar Raya bersama FWK adalah dengan memperlebar isu ke isu-isu lain selain isu bencana. Strategi memperlebar isu dilakukan pedagang korban bencana sebagai bagian dari upaya menggalang dan memperkuat dukungan dari berbagai kalangan dan kelompok yang memiliki rasa yang sama. Upaya memperlebar isu yang dilakukan oleh pedagang korban bencana (Meminjam istilah E. Durkheim) dengan membangun solidaritas organis antara sesama korban kebijakan pembangunan kota. Isu gerakan protes berkembang ke kebijakan pembangunan kota lain seperti Warga Korban Gempa Tahun 2007 dengan kasus bantuannya tidak disalurkan oleh Pemko Padang, Warga Teluk Sirih dengan kasus pencaplokan paksa tanah, warga Kurao Pagang dengan kasus pencaplokan paksa tanah, warga Pasia Nan Tigo kasus kasus manuggal jalan BSD II.

\section{c. Bentuk dan Strategi Protes Bersama PBHI Sumbar}

Pasca kriminalisasi pedagang dalam aksi demonstrasi bersama FWK tanggal 10 
Februari 2010, gerakan protes dalam bentuk demonstrasi mulai berkurang. Selain rasa takut, energi pedagang banyak tersedot untuk mendampingi 6 anggota mereka yang ditahan oleh kepolisian. Di sisi lain, tekanan dari pemerintah untuk mengosongkan Inpres II, II dan IV terus berlanjut. November 2010 pemko Padang kembali memerintahkan pedagang untuk mengosongkan inpres II, III dan IV karena akan segera dirobohkan untuk dibangun kembali. Sadar dengan kekuatan yang ada, beberapa pedagang berinisiatif untuk meminta pendampingan secara hukum oleh PBHI Sumbar. Terhitung Januari 2010, satu per satu pedagang pasar secara individu memberikan kuasa kepada PBHI Sumbar untuk mendampingi mereka dalam penolakan rekonstruksi Inpres II, III dan IV.

Pola dan strategi yang digunakan oleh pedagang bersama PBHI tidak dalam bentuk demonstrasi. Setiap pedagang yang memberi kuasa hukum diberi penguatan tentang substansi pemberian kuasa yang mereka serahkan kepada PBHI Sumbar, hak dan kewajiban mereka sebagai korban bencana sesuai dengan UU, pengetahuan hukum seputar penanggulangan bencana. Penguatan dilakukan oleh PBHI Sumbar dengan tujuan memberikan pemahaman kepada pedagang tentang gerakan dan arah perjuangan yang mereka lakukan. Sehingga dengan penguatan tersebut, pedagang dapat secara mandiri dan bersama-sama menyusun strategi gerakan yang mereka lakukan.

Pendekatan protes yang dilakukan pedagang bersama PBHI Sumbar adalah pendekatan hukum sesuai dengan UU yang berlaku terutama UU tentang kebencanaan. Sehingga dalam strateginya, pedagang korban bencana tidak pernah melakukan aksi unjuk rasa dan demonstrasi. Strategi yang digunakan oleh pedagang bersama PBHI lebih banyak pada penguatan hukum bagi pedagang sendiri pada internal pedagang.
Untuk eksternal, pedagang melakukan pendekatan dengan lembaga-lembaga lain dalam mengumpulkan dukungan bagi perjuangan mereka. Dengan menggunakan pendekatan hukum, strategi yang digunakan pedagang dominan menyurati lembagalembaga yang berhubungan dengan kebijakan penanggulangan bencana Pasar Raya Padang. Dengan DPRD Kota Padang, pedagang tidak lagi melakukan unjuk rasa, tapi lebih menekankan pada dialog dan lobby dengan pendekatan aturan perundang-undangan yang berlaku. Lobby, hearing dan dialog juga dilakukan dengan pemerintah kota.

\section{Kesimpulan}

Dalam masyarakat yang dinamis, konflik adalah keniscayaan. Keniscayaan itu mengejawantah dalam berbagai pola interaksi dan relasi individu dan kelompok yang ada dalam masyarakat. Meskipun konflik adalah keniscayaan, ia sesungguhnya dapat dihindari. Dalam kasus rehabilitasi dan rekonstruksi Pasar Raya Padang, konflik dalam bentuk protes pedagang semestinya dapat dihentikan dan bahkan dihindari. Tentu saja dengan adanya common will dari pembuat kebijakan, yaitu pemerintah kota Padang.

Melihat pada pola dan bentuk konflik yang terus bertahan, dapat dikatakan bahwa pemicu bertahannya konflik adalah karena tidak adanya kesamaan antara pemerintah dengan pedagang dalam upaya membangun ulang pasar yang sudah roboh. Pemerintah menginginkan pembangunan ulang secara keseluruhan dengan mekanisme investasi, sementara pedagang menginginkan pembangunan dengan menguikuti peraturan perundang-undangan. Perbedaan persepsi ini yang menjadi pemicu bertahannya konflik hingga sangat lama.

Dalam proses pembangunan, sebagai penyelenggara Negara, Pemerintah mesti mengikuti peraturan yang sudah ada. Dalam 
kasus pembangunan Pasar Raya Padang, justru pedagang yang menginginkan pembangunan sesuai dengan paraturan perundang-undangan, sementara pemerintah justru tidak mengikuti peraturan perundangan. Jika saja pemerintah mengikuti peraturan, tentu konflik tidak terjadi dan tidak akan bertahan lama.

\section{Daftar Pustaka}

Ardinal. Kota Padang Punya Banyak Potensi Untuk Dikembangkan. Padang : Lentera, 2005.

Afrizal. Sosiologi Konflik Agraria. Protes-protes agraria dalam masyarakat kontemporer. Padang: Andalas University Press, 2006

Fauzi, Noer. Memahami Gerakan-Gerakan Rakyat Dunia Ketiga. Yogyakarta: Insist, 2005.

Johnson, Doyle Paul. Teori Sosiologi Klasik dan Modern. Jakarta: Gramedia, 1994.
Koentjaraningrat. Metodologi Penelitian Masyarakat. Jakarta: LIPI, 1973.

Republik Indonesia, Undang-Undang No. 24 Tahun 2007, Tentang Penanggulangan Bencana.

Sztompka, Piotr. Sosiologi Perubahan Sosial. Jakarta: Prenada, 2006.

Taufik, Muhammad. Perlawanan Pedagang Kaki Lima Terhadap Perda; Studi Atas Resistensi Pedagang 'Kaki Lima' Minang Di Yogyakarta. Yogyakarta: Tesis Pada Pascasarjana UGM, , 2003.

Koran Harian Singgalang, 30 Oktober 2009.

Koran Harian Padang ekspress, 15 Oktober 2009. 
